\title{
Folk and Open-air Museums.*
}

THOUGH the expression 'folk museum' is loosely 1 used, it is generally understood, like "folk-lore', to relate to the ordinary people, the rank and file of the population, the labourers, the artisans, the craftsmen, as opposed to the ruling class. Such collections of indigenous products have great historical value. They deserve to be regarded as almost the only means of preserving visible records of the national characteristics. The humbler the art or the handicraft, the more important it is from this point of view.

In England it is only recently that the regrettable disappearance of the outward and visible signs of the inner history of the people has been fully realised, and consequently it is only recently, and owing to the very rapid growth of local museums, that systematic attempts have been made and are being made to preserve them. The example for this systematic effort was set in Sweden by Dr. Arthur Hazelius, the founder of the Nordiska Museum, which is now one of the glories of Stockholm. This great scheme has been an inspiration for all subsequent attempts to illustrate fully the life of past ages.

It is important, however, to make a clear distinction between two quite different things, although they are adjacent and form part of one scheme in Stockholm. The first is the 'open-air museum' of the Skansen type, in which are re-erected the primitive dwellings, huts, cottages, workshops, windmills, bakehouses, ancient churches, and so on, that would otherwise have been destroyed or converted to other uses; and in these are generally placed the furniture, the appliances, and the decorations that belong to them. The second is the 'folk museum ', which contains materials illustrating bygone life and thought at different periods or in different districts of the country; but these materials are not placed in their proper setting, they are brought together and exhibited according to purpose or material, and generally displayed in museum cases in such a sequence as either to compare the customs and handicrafts of one district with those of another, or to illustrate the development of an art or an industry. The open-air museum and the folk museum supplement each other.

There is, in addition, another sort of collection often included under the name 'folk museum', namely, the old house preserved in its original form and in its original place, and containing a display of contemporary furniture and household equipment. There is yet another type of dwelling, namely, the old house or cottage preserved in its primitive simplicity so as to present the appearance of an inhabited dwelling without anything of the museum about it; such is Ann Hathaway's Cottage. It is of such buildings that an open-air museum' partly consists.

Let us then confine the term 'open-air museum ', for lack of a better, to the Skansen type, "folk' museum' to the Nordiska type, and let us further distinguish between the 'period museum', an old house filled with contemporary exhibits, and the 'period house' or 'period cottage', which has no museum exhibits but reproduces domestic life.

Finally there is the "period room ', either an original transported from a house which has been destroyed, or a facsimile, in which an attempt is made to reproduce the conditions of life, whether in a mansion or in a cottage. Such rooms generally constitute a separate exhibit in a museum.

* Abridged from a paper contributed by Sir Henry Miers, F.R.S., to * Abridged from a paper contributed by Sir Henry "Miers, F. R. ., to the British Association at Bristol on Sept. 4

No. 3180, VoL. 126]

\section{State of Affatrs in the British Isles.}

1. Open-air Museums.--In 1912 an attempt was made by a group of influential persons to press the advantages of the Crystal Palace grounds as an ideal site for such an open-air exhibit of a national character. Possibilities for local exhibits of this type have been considered, but nothing has materialised.

Recently the Report of the Royal Commission on National Museums and Galleries has considered the subject from the national aspect and has definitely recommended that a national open-air museum should be established in London ; two appropriate sites mentioned are the Botanic Gardens in Regent's Park and the grounds of Chiswick House.

The question has since been taken up by a joint committee initiated by the Royal Anthropological Institute and containing representatives of the Royal Society, the Royal Society of Arts, the Museums Association, and the British Association. This committee has unanimously recommended the Botanic Gardens site as the most suitable, and has approached the Government departments concerned, urging that early action should be taken.

2. Folk Museums.-Institutions wholly devoted to this subject, like the Nordiska Museum, are also unknown in the British Isles. The fine collection of peasant arts made by the late Master of the Charterhouse is now an annexe to the Educational Museum at. Haslemere and is mainly concerned with northern Europe.

3. Period Museums.-Of these we have a considerable number, but comparatively few of them relate to the life of humbler folk. I may instance the Priest. House at West Hoathly, the Ancient House at Thetford, the Greenland Fishery at King's Lynn, as typical examples.

4. Period Cottages.--As a good example may be mentioned Ann Hathaway's Cottage, but very few cottage-dwellings have been preserved free from the museum taint : most of them contain showcases.

5. Period Rooms.-Most of these again, as at Norwich and elsewhere, are typical of the life of wealthy and cultured folk. In the National Museum at Cardiff, in the Museums at Salisbury, St. Albans, and perhaps elsewhere, attempts have been made to reconstruct a kitchen or some living-room with its appropriate furniture and utensils.

6. Folk (Museum) Exhibits.-Of these there are abundant examples, rich in valuable material gathered together either as local 'bygones' or placed among ethnographical collections. Conspicuous are the PittRivers Museums at Farnham and Oxford, the collections at Huddersfield and at Hull, and many of the national and larger provincial museums, including also such local collections as those at Bedford, Luton, Newark, Bolton (Hall-i'-th'-Wood), Worthing, Lancaster.

Finally, some illustrations of the life of craftsmen may be gleaned from museums which illustrate special pursuits or handicrafts ; such are, however, extremely rare in Great Britain, and almost the only one which aims at something like completeness is the Museum of Fisheries and Shipping at Hull.

From this short survey it is clear that there is a vast amount of material from which the life, arts, industries, and customs of the people might be illustrated, but it is buried in other collections. It is equally clear that the real need in Great Britain is for an English or British folk museum associated with an open-air museum. 
State of Affairs in Foreign Countries.

\section{Open-air Museums.}

Sweden.-There are museums of the Skansen type in Sweden not only at Stockholm but also in many other parts of the country. There are no less than 200 openair collections. in Sweden alone. Skansen itself contains 117 separate buildings, records 700,000 visitors in a year, and occupies 60 acres.

Sweden also possesses a number of quite small rillage enterprises, where a field or small group of ottages have been set aside for this purpose. One If these at Bunge, started in 1907, has since become an open-air museum of considerable importance. A special feature of this museum is the ancient burial. ground, showing various methods of burial and types of burial-stones dating from the time of the Vikings.

Norway.-There is at Oslo the Norsk Museum, which was opened in 1902 and now covers an area of 35 acres, upon which are re-erected old farm-houses of different periods, and an attempt is made to re-create old streets with houses that have disappeared or are fast disappearing. At Lillehammer there is the Sandvig Collection, which contains 75 ancient buildings.

Denmark.-At Aarhus there is Den Gamle By (The old Town), which was started about sixteen years ago by the re-erection of a Burgomaster's house and has since grown to a considerable size.

Finland.-At Helsingfors, in the Isle of Folesön, there is a large museum, covering an area of 25 acres, which was founded in 1909 this consists of more than thirty buildings of various types and periods.

Holland.-The Nederlandsch Openluchtmuseum at Arnhem consists of 20 buildings, covering an area of 75 acres; this was opened in 1918.

Rumania.-At Cluj an excellent example of an openair museum is being formed with the object of exhibiting the typical peasant culture of the Rumanians and other nationalities in Rumania, by means of their characteristic peasant buildings and occupations. The collections will consist of typical houses brought from each district, and in each of these houses a family from the same district will live to show the type, costume, typical customs, and occupations. In addition to the typical original buildings, it is intended to erect an open-air theatre for the purpose of peasant festivals, and so on.

2. Folk Museums.-Museums of this type similar to the Nordiska Museum at Stockholm, though many of them are on a small scale, exist in many other places. Examples are the Museum at Karlskrona in Blekinge, Sweden, and the Engadine Museum at St. Moritz.

\section{Conclusion.}

It will be seen from this how late we are in any systematic endeavour to preserve and accumulate such illustrations of peasant and artisan life in Great Britain. The folk museum should undoubtedly, where possible, be associated with and supplementary to the open-air museum. It is deplorable that so many old buildings and other survivals from past times have been irrevocably lost in recent years. But the national conscience is obviously awakening to the value of such things, and determined efforts are now being made in many quarters not only to preserve the amenities of the countryside but also to conserve the old houses and cottages which are in danger of destruction. But in too many instances the advance of town building and the alteration of the countryside threaten the actual existence of many a cottage, wind-mill, forge, or other relic of the past which might be saved and re-erected in an open-air museum. Here again, where these can be retained in their own district, that should be done, and for this purpose it is to be hoped that many localities will follow the Swedish example and preserve and maintain such structures in a local enclosure. The institution of a national enclosure should not in the least interfere with such local efforts, but should serve as an example and inspiration to towns and villages all over the country.

\section{The International Union of Geodesy and Geophysics.}

THE fourth meeting of the International Union of Geodesy and Geophysics was held at Stockholm on Aug. 15-23, though the Section of Geodesy found it necessary to begin three days earlier in order to get through a long programme of work. The meeting was very well attended, representatives of thirty countries being present and numbering more than two hundred. A number of other scientific men attended by invitation, among whom were Dr. Linke, of the Geophysical Institute at Frankfurt; Dr. E. Kohlschülter, of the Geodetic Institute at Potsdam; Dr. R. Schreiter, of Freiburg; and Dr. V. Conrad and Dr. Hopffner, of Vienna.

The opening meeting was held on Friday, Aug. 15, in the Concert Hall, where Dr. E. Trygger, the Chancellor of the Universities and chairman of the Swedish National Committee, welcomed the delegates. M. Ch. Lallemand, the president of the Union, replied and expressed the thanks of the delegates for the excellent arrangements which had been made for their comfort. The other meetings of the Union, as well as those of the Sections, were held in the Parliament House, where ample accommodation was available for all.

In the Section of Geodesy, reports were presented by the delegates of the various countries on the progress made in geodetic work since the last meeting of the Union in Prague in 1927, and a number of special points were discussed. These will be published in the Bulletin and the Memoirs of the Section in due course. Much interest was taken in the account which Dr. Vening Meinesz gave of his recent determinations of gravity at sea, made from a submarine in the neighbourhood of Java, in the Pacific Ocean, and elsewhere. A very interesting discussion took place, and a strong recommendation that work of this character should be undertaken in the Bay of Bengal and other eastern waters was approved, and was later adopted by the General Assembly of the Union.

The death of Prof. H. H. Turner, who was taken ill as he was about to deliver his address as president of the Section of Seismology, cast a gloom over its meetings, but nevertheless a large amount of useful work was done. This Section, as well as that of Geodesy, both of which have to discuss and publish a large collection of data that would not otherwise be readily available to international workers, find their resources far from adequate, and Prof. Turner's address brought the urgent needs of the Section in this respect before the delegates. The work which is being done at Oxford, as well as that under Prof. E. Rothé at Strasbourg, is in need of a fuller measure of support, and resolutions to this effect were adopted by the Section. No successor to Prof. Turner was appointed, but the vice-president, Prof. E. Oddone, was authorised to act as president for the time being.

No. 3180 , VoL. 126] 